\title{
DAMPAK RASIO KEUANGAN TERHADAP PERINGKAT OBLIGASI PADA PERUSAHAAN JASA SEKTOR KONSTRUKSI YANG TERDAFTAR DI BEI
}

\author{
Novi Herlina Sari ${ }^{1^{*}}$ \\ 1)Jurusan Akuntansi, Fakultas Ekonomi dan Bisnis, Universitas Prof. DR. HAMKA, Indonesia \\ *Email corresponding author: novilina60@gmail.com
}

\begin{abstract}
ABSTRAK
Penelitian ini berjudul "Dampak Rasio Keuangan Terhadap Peringkat Obligasi Pada Perusahaan Jasa Sektor Konstruksi Yang Terdaftar Di Bei". Berinvestasi melalui obligasi haruslah berhati-hati, para investor harus menghindari risiko default atau gagal bayar. Salah satu cara untuk mengindarinya adalah investor memerlukan sinyal atau informasi yang menandakan kemungkinan terjadinya risiko gagal bayar, yaitu dengan memperhatikan peringkat obligasi. Penelitian ini bertujuan untuk mengetahui bagaimana hubungan antara rasio keuangan terhadap peringkat obligasi pada perusahaan jasa sektor konstrusi yang terdaftar di Bursa Efek Indonesia (BEI) dan obligasinya di peringkati oleh PT Pemeringkat Efek Indonesia (PT PEFINDO) tahun 2013-2017. Analisis data yang digunakan adalah analisis Regresi Logistik Ordinal karena variabel dependen yang digunakan berskala ordinal (peringkat). Dalam penelitian ini teknik pengambilan sampel menggunakan metode purposive sampling dan terpilih sebanyak 6 perusahaan yang sesuai dengan kriteria. Hasil pengujian hipotesis, menyatakan bahwa variable rasio aktivitas dan profitabilitas berpengaruh secara positif terhadap peringkat obligasi. Rasio likuiditas berpengaruh negatif terhadap peringkat obligasi, sedangkan rasio solvabilitas tidak berpengaruh terhadap peringkat obligasi.
\end{abstract}

Kata kunci : Peringkat obligasi, likuiditas, solvabilitas, aktivitas dan profitabilitas

\begin{abstract}
This study is entitled "The Impact of Financial Ratios on Bond Ratings in Construction Sector Service Companies Registered in IDX". Investing through bonds must be careful, investors must avoid the risk of default or default. One way to avoid this is that investors need signals or information that indicate the possibility of default risk, namely by paying attention to bond ratings. This study discusses the relationship between financial ratios of service ratings of construction companies listed on the Indonesia Stock Exchange (IDX) and bonds are summarized by Indonesian Rating Agency (PT PEFINDO) in 2013-2017. Analysis of the data used is Ordinal Logistic Regression analysis because the dependent variable used is ordinal scale (ranking). In this study the sampling technique using purposive sampling method and selected as many as 6 companies in accordance with the criteria. The results of testing the hypothesis analysis, states that the ratio and profitability variables are positively related to bond ratings. The ratio of negative liquidity to ratings, while the solvency ratio is not determined against the rating.
\end{abstract}

Keywords: Bond rating, liquidity, solvency, activity and profitability

\section{PENDAHULUAN}

Berinvestasi pada obligasi merupakan alternatif yang cenderung lebih aman dibandingkan dengan instrumen keuangan lainnya. Salah satu keuntungan dari obligasi adalah ketika suatu perusahaan mengalami likuidasi maka pemegang obligasi memiliki hak pertama atas aset perusahaan, karena adanya suatu kontrak perjanjian pelunasan. Berinvestasi melalui obligasi selain menguntungkan juga memiliki kelemahan, yaitu adanya resiko gagal bayar. Sebelum membeli obligasi, investor harus memerhatikan default risk. Default risk adalah peluang dimana emiten yang akan mengalami kondisi tidak mampu membayar kewajiban keuangannya. Untuk menghindari risiko tersebut, maka investor perlu memperhatikan beberapa hal salah satunya 
adalah informasi mengenai peringkat obligasi.

Peringkat obligasi merupakan sinyal dari kinerja suatu perusahaan yang digunakan sebagai dasar pembuatan keputusan bagi pengguna informasi. Investor harus memiliki kemampuan dalam membaca sinyal yang menandakan kemungkinan risiko default (gagal bayar). Salah satu faktor penilaian peringkat obligasi adalah mencakup unsur keuangan, maka perusahaan cenderung mendorong manajer untuk meningkatkan rasio keuangan agar mempengaruhi perolehan peringkat obligasi. Rasio keuangan yang digunakan dalam penelitian ini adalah rasio likuiditas, rasio solvabilitas, rasio aktivitas, dan rasio profitabilitas.

Rasio likuiditas menggambarkan kemampuan perusahaan untuk menyelesaikan kewajiban jangka pendeknya (Harahap, 2011: 301). Rasio likuiditas adalah rasio untuk mengetahui kemampuan perusahaan membiayai operasi dan memenuhi kewajiban keuangan pada saat ditagih (Munawir, 2015: 238). Rasio likuiditas yang umum dipergunakan, yaitu Current Ratio (CR). Current Ratio merupakan rasio untuk mengukur kemampuan perusahaan membayar kewajiban jangka pendek atau utang yang segera jatuh tempo pada saat ditagih. Dengan kata lain, seberapa banyak aktiva lancar yang tersedia untuk menutupi kewajiban jangka pendek yang segera jatuh tempo. Semakin tinggi tingkat rasio likuiditas perusahaan, maka semakin tinggi peringkat obligasi perusahaan tersebut. Hal ini sejalan dengan penelitian Dinik Kustiyaningrum, Elva Nuraina dan Anggita Langgeng Wijaya (2016) dan Rizka Dewi Oktaviyani (2013). Namun bertentangan dengan penelitian Akbar Susanto (2015) serta I Made Bana Partha dan Gerianta Wirawan Yasa (2016).

Rasio solvabilitas merupakan rasio yang digunakan untuk mengukur sejauh mana aktiva perusahaan dibiayai dengan hutang. Artinya berapa besar beban hutang yang ditanggung perusahaan dibandingkan dengan aktivanya. Dalam arti luas dikatakan bahwa rasio solvabilitas digunakan untuk mengukur kemampuan perusahan untuk membayar seluruh kewajibannya, baik jangka pendek maupun jangka panjang apabila perusahaan dibubarkan (likuidasi) (Kasmir, 2013: 151). Rasio solvabilitas adalah rasio yang menunjukkan bagaimana perusahaan mampu untuk mengelola utangnya dalam rangka memperoleh keuntungan dan juga mampu melunasi kembali utangnya (Irham Fahmi, 2014: 59). Rasio solvabilitas diukur dengan menggunakan Debt to Equity Ratio (DER). Rasio ini berguna untuk mengetahui jumlah dana yang disediakan peminjam (kreditur) sebagai jaminan utang dengan pemilik perusahaan. Semakin tinggi nilai Debt to Equity Ratio menunjukkan semakin besar nilai utang terhadap total ekuitas, yang artinya menunjukkan ketergantungan perusahaan terhadap pihak luar (kreditur). Sehingga perusahaan juga akan menanggung risiko yang tinggi. Semakin besar rasio solvabilitas perusahaan, maka semakin besar risiko gagal bayar yang menyebabkan rendahnya peringkat obligasi yang diberikan. Hal ini sejalan dengan penelitian yang dilakukan oleh serta I Made Bana Partha dan Gerianta Wirawan Yasa (2016) dan Marwa Mohamed (2015). Namun bertentangan dengan penelitian Ratih Umroh Mahfudhoh (2014) serta Dinik Kustiyaningrum, Elva Nuraina dan Anggita Langgeng Wijaya (2016).

Rasio aktivitas merupakan rasio untuk mengetahui kemampuan perusahaan dalam melakukan aktivitas perusahaan sehari-hari atau kemampuan perusahaan dalam penjualan, penagihan piutang maupun pemanfaatan aktiva yang dimiliki (Munawir, 2015: 238). Rasio yang menggambarkan sejauh mana suatu perusahaan mempergunakan sumber daya yang dimilikinya guna menunjang aktivitas perusahaan, dimana penggunaan aktivitas ini dilakukan secara sangat maksimal dengan maksud memperoleh hasil yang maksimal (Irham Fahmi, 2014: 132). Rasio aktivitas diukur dengan Total Assets Turnover (TAT). Apabila aktivitas perusahaan tinggi, maka kemungkinan besar obligasi perusahaan masuk dalam investment grade, karena dengan penjualan yang tinggi perusahaan akan mampu menghasilkan laba yang tinggi. Dengan laba yang 
tinggi perusahaan mampu untuk memenuhi segala kewajibannya kepada para investor. Pembayaran bunga yang tepat pada waktunya, memberikan daya tarik bagi investor untuk menanamkan investasi pada perusahaan. Semakin tinggi rasio aktivitas, maka semakin baik peringkat obligasi perusahaan tersebut. Hal ini sejalan dengan penelitian Dian Wahyu Kurniawan (2016), namun bertentangan dengan penelitian Rizka Dewi Oktaviyani (2013) dan Akbar Susanto (2015).

Rasio profitabilitas merupakan rasio untuk menilai kemampuan perusahaan dalam mencari keuntungan. Rasio ini juga memberikan ukuran tingkat efekifitas manajemen suatu perusahaan, hal ini ditunjukan oleh laba yang dihasilkan dari penjualan dan pendapatan investasi. Intinya adalah penggunaan rasio ini menunjukkan efisiensi perusahaan (Kasmir, 2013: 114). Rasio profitabilitas menggambarkan kemampuan perusahaan mendapatkan laba melalui semua kemampuan, dan sumber yang ada seperti kegiatan penjualan, kas, modal, jumlah karyawan, jumlah cabang, dan sebagainya (Harahap, 2011: 304). Rasio yang digunakan adalah Net Profit Margin (NPM). Rasio ini menjelaskan kemampuan perusahaan untuk menghasilkan laba pada tingkat penjualan tertentu. Semakin tinggi tingkat profitabilitas perusahaan, semakin rendah risiko gagal bayar dan semakin baik peringkat obligasi yang diberikan terhadap perusahaan tersebut. Hal ini sejalan dengan penelitian I Made Bana Partha (2016) dan Marwa Mohamed (2015). Namun bertentangan dengan penelitian Rahmat Dwi Winardi (2013) dan Ratih Umroh Mahfudhoh (2014)

Penelitian mengenai faktor-faktor yang mempengaruhi peringkat obligasi perusahaan telah banyak dilakukan dan semakin berkembang. Diantaranya adalah penelitian yang dilakukan oleh Rahmat Dwi Winardi (2013), dengan tujuan untuk menguji bagaimana pengaruh faktor akuntansi dan non akuntansi terhadap prediksi peringkat obligasi dari 144 obligasi yang diterbitkan oleh perusahaan keuangan yang terdaftar di BEI selama periode 2010-2012 dan diperingkat oleh PT PEFINDO. Hasil penelitian ini menunjukkan bahwa ukuran perusahaan berpengaruh positif signifikan terhadap prediksi peringkat obligasi, sedangkan Net Profit Margin dan reputasi auditor berpengaruh negatif signifikan terhadap prediksi peringkat obligasi. Penelitian ini tidak berhasil membuktikan bahwa leverage, Return on Asset, jaminan obligasi dan umur obligasi berpengaruh secara signifikan terhadap peringkat obligasi.

Lalu penelitian yang dilakukan oleh Ratih Umroh Mahfudhoh (2014), dengan tujuan untuk memberikan bukti empiris pada faktor-faktor apa saja yang mungkin mempengaruhi prediksi peringkat obligasi atas 74 perusahaan yang terdaftar di PT PEFINDO selama periode 2009-2012 kecuali Bank dan Lembaga Keuangan. Penelitian ini menunjukkan bahwa likuiditas, profitabilitas, leverage, produktivitas, pertumbuhan perusahaan, jaminan dan jatuh tempo adalah variabel yang tidak signifikan untuk menentukan peringkat obligasi, sedangkan ukuran perusahaan serta laba ditahan adalah variabel yang signifikan untuk menentukkan peringkat obligasi.

Selanjutnya penelitian yang dilakukan oleh Akbar Susanto (2015), dengan tujuan untuk mengetahui faktor-faktor yang mempengaruhi peringkat obligasi pada perusahaan non keuangan tahun 2011-2013. Hasil penelitian menunjukkan bahwa variabel umur obligasi dan reputasi auditor terbukti berpengaruh positif signifikan terhadap peringkat obligasi. Sementara pertumbuhan perusahaan berpengaruh negatif terhadap peringkat obligasi. Sedangkan variabel likuiditas, produktivitas, jaminan dan kepemilikan manajerial tidak berpengaruh terhadap peringkat obligasi.

Penelitian ini mengacu pada pengungkapan peringkat yang diterbitkan oleh PT PEFINDO karena perusahaan ini merupakan pemeringkat tertua dan terpercaya di Indonesia, serta telah melakukan pemeringkatan terhadap lebih dari 500 perusahaan dan pemerintah daerah. Konstruksi merupakan suatu kegiatan membangun sarana maupun prasarana. Pemilihan 
perusahaan sektor jasa kontruksi karena sedang meningkatnya pembangunan infrastruktur di Indonesia beberapa tahun terakhir yang menjadi fokus pemerintah yang melibatkan perusahaanperusahaan dibidang konstruksi. Pemilihan untuk berinvestasi pada obligasi dalam sektor konstruksi harus diwaspadai karena rentan bila terjadi risiko-risiko bisnis yang mengancam arus kasnya. Sebagaimana disampaikan dalam berita yang dimuat dalam market.bisnis.com "Proporsi utang emiten-emiten sektor konstruksi yang semakin tinggi menjadikan surat utang emitenemiten di sektor ini relatif rentan bila terjadi risiko-risiko bisnis yang mengancam arus kasnya. Emiten-emiten sektor konstruksi, khususnya dari keluarga BUMN memiliki tanggung jawab tinggi dari pemerintah untuk mendukung pembangunan infrastruktur sesuai target pemerintah. Hal ini menjadi latar belakang agresifnya BUMN memburu utang baru, baik melalui sindikasi perbankan, obligasi domestik, maupun obligasi global. Bahkan, sejumlah BUMN untuk pertama kalinya mulai menjajaki instrumen surat utang di pasar modal." (Caesario, 2018).

Ketidaksesuaian hasil beberapa penelitian di atas menjadi latar belakang untuk melakukan penelitian selanjutnya. Selain adanya risiko gagal bayar dan mulainya perusahaan konstruksi menjajaki instrumen surat utang di pasar modal, penelitian ini juga dimotivasi oleh informasi yang dipakai investor untuk memprediksi peringkat obligasi kadang tidak sesuai dengan kondisi keuangan dan kondisi perusahaan yang sebenarnya. Sehingga, investor perlu mengetahui faktor-faktor yang mempengaruhi peringkat obligasi perusahaan. Peringkat yang dikeluarkan oleh lembaga pemeringkat inilah yang dapat dijadikan sinyal untuk berinvestasi obligasi. Variabel yang dipakai dalam penelitian ini adalah berbagai macam risiko rasio-rasio keuangan, semakin baik rasio-rasio keuangan tersebut semakin tinggi rating obligasi. (Brigham, 2014). Dalam penelitian ini variabel yang digunakan meliputi rasio likuiditas yang diwakili oleh Current Ratio (CR), solvabilitas yang diwakili oleh Debt to Equity Ratio (DER), aktivitas yang diwakili oleh Total Assets Turnover (TAT), dan profitabilitas yang diwakili oleh Net Profit Margin (NPM). Penelitian mengenai peringkat obligasi di sektor jasa sektor konstruksi masih terbatas. Sehingga mendorong peneliti untuk melakukan penelitian lanjutan yang diharapkan dapat memberikan hasil yang memadai dengan data yang lebih relevan dengan kondisi sekarang ini. Penelitian bertujuan untuk mengetahui pengaruh dari rasio likuiditas, solvabilias, aktivititas, dan profitabilitas yang tercantum dalam laporan keuangan, terhadap peringkat obligasi yang dikeluarkan oleh PT PEFINDO pada perusahaan jasa sektor kontruksi yang terdaftar di BEI tahun 2013-2017.

\section{TINJAUAN PUSTAKA DAN PERUMUSAN HIPOTESIS}

\section{Teori Sinyal}

Setiap orang, baik investor maupun manajer memiliki informasi yang sama tentang prospek suatu perusahaan. Kesamaan informasi tersebut biasa dinyatakan sebagai informasi simetris. Akan tetapi pada kenyataannya yang sering terjadi adalah asimetri informasi, yaitu ketidaksamaan informasi yang dimiliki oleh manajer dan investor. Teori sinyal adalah sebagai suatu tindakan yang diambil oleh manajemen suatu perusahaan untuk menilai prospek perusahaan untuk masa mendatang (Brigham, 2014). Sinyal yang diberikan perusahaan kepada calon investor adalah adanya penerbitan laporan keuangan oleh perusahaan. Hal tersebut dilakukan untuk menyampaikan kondisi perusahaan kepada masyarakat luas karena melalui penyampaian informasi tersebut dapat meyakinkan masyarakat untuk menanam modalnya pada perusahaan tersebut.

Salah satu sinyal positif yang diberikan perusahaan untuk menarik calon investor adalah peringkat obligasi. Peringkat obligasi memberikan informasi keamanan obligasi yang diterbitkan 
oleh perusahaan tersebut. Informasi berupa pemberian peringkat obligasi yang dipublikasikan diharapkan dapat menjadi sinyal atas kondisi keuangan perusahaan dan menggambarkan kemungkinan yang terjadi terkait dengan utang yang dimiliki.

\section{Obligasi}

Menurut Irham Fahmi (2014:318) obligasi merupakan suatu surat berharga yang dijual kepada publik, dimana disana dicantumkan berbagai ketentuan yang menjelaskan berbagai hal seperti nilai nominal, tingkat suatu bunga, jangka waktu, nama penerbit dan beberapa ketentuan lainnya yang menjelaskan dalam undang-undang yang disahkan oleh lembaga yang terkait. Semua obligasi yang diterbitkan oleh perusahaan memiliki resiko default kecuali obligasi yang diterbitkan oleh pemerintah. Untuk menghindari risiko tersebut investor harus mendapatkan informasi atau sinyal yang tercermin dari peringkat obligasi. PT PEFINDO mengeluarkan peringkat dari idD hingga idAAA, di mana peringkat idD merupakan default dan peringkat tertinggi yaitu idAAA.

\section{Variabel-variabel yang diduga mempengaruhi peringkat obligasi}

Rasio likuiditas menggambarkan kemampuan perusahaan untuk menyelesaikan kewajiban jangka pendeknya (Harahap, 2011:301). Rasio likuiditas yang umum dipergunakan, yaitu Current Ratio (CR). CR merupakan rasio untuk mengukur kemampuan perusahaan membayar kewajiban jangka pendek atau utang yang segera jatuh tempo pada saat ditagih. Dengan kata lain, seberapa banyak aktiva lancar yang tersedia untuk menutupi kewajiban jangka pendek yang segera jatuh tempo. Semakin tinggi tingkat rasio likuiditas perusahaan, maka semakin tinggi peringkat obligasi perusahaan tersebut. Maka dari itu dapat dirumuskan hipotesis sebagai berikut:

$\mathrm{H}_{1}$ : Current Ratio berpengaruh terhadap peringkat obligasi

Rasio solvabilitas dalam arti luas dikatakan bahwa rasio solvabilitas digunakan untuk mengukur kemampuan perusahan untuk membayar seluruh kewajibannya, baik jangka pendek maupun jangka panjang apabila perusahaan dibubarkan (likuidasi) (Kasmir, 2013:151). Rasio solvabilitas dapat diukur dengan Debt to Equity Ratio (DER). DER berguna untuk mengetahui jumlah dana yang disediakan peminjam (kreditur) sebagai jaminan utang dengan pemilik perusahaan. Semakin tinggi nilai DER menunjukkan semakin besar nilai utang terhadap total ekuitas, yang artinya menunjukkan ketergantungan perusahaan terhadap pihak luar (kreditur). Sehingga perusahaan juga akan menanggung risiko yang tinggi. Semakin besar rasio solvabilitas perusahaan, maka semakin besar risiko gagal bayar yang menyebabkan rendahnya peringkat obligasi yang diberikan. Berdasarkan uraian tersebut maka dapat dirumuskan hipotesis sebagai berikut:

$\mathrm{H}_{2}$ : Debt to equity ratio berpengaruh terhadap peringkat obligasi

Rasio aktivitas merupakan rasio yang menggambarkan sejauh mana suatu perusahaan mempergunakan sumber daya yang dimilikinya guna menunjang aktivitas perusahaan, dimana penggunaan aktivitas ini dilakukan secara sangat maksimal dengan maksud memperoleh hasil yang maksimal (Irham Fahmi, 2014:132). Rasio aktivitas diukur dengan Total Assets Turnover (TAT). Perusahaan dengan tingkat aktivitas yang tinggi cenderung akan mampu menghasilkan pendapatan usaha yang lebih tinggi. Sehingga perusahaan dengan tingkat aktivitas yang tinggi akan mampu memenuhi kewajibannya dengan baik. Maka dari itu dapat dirumuskan hipotesis sebagaiberikut:

$\mathrm{H}_{3}$ : Total Assets Turnover berpengaruh terhadap peringkat obligasi

Rasio profitabilitas merupakan rasio untuk menilai kemampuan perusahaan dalam mencari keuntungan. Rasio profitabilitas menggambarkan kemampuan perusahaan mendapatkan laba 
melalui semua kemampuan, dan sumber yang ada seperti kegiatan penjualan, kas, modal, jumlah karyawan, jumlah cabang, dan sebagainya (Harahap, 2011:304). Rasio yang digunakan adalah Net Profit Margin (NPM). Semakin tinggi tingkat profitabilitas perusahaan, semakin rendah risiko gagal bayar dan semakin baik peringkat obligasi yang diberikan terhadap perusahaan tersebut. Maka dapat dirumuskan hipotesis sebagai berikut:

$\mathrm{H}_{4}$ : Net Profit Margin (NPM) berpengaruh terhadap peringkat obligasi

\section{METODE PENELITIAN}

Populasi dalam penelitian ini adalah perusahaan keuangan yang terdaftar di Bursa Efek Indonesia dari tahun 2013 sampai 2017. Ada 28 perusahaan jasa sektor konstruksi yang merupakan perusahaan publik yang terdaftar di Bursa Efek Indonesia. Metode penentuan sampel dalam penelitian ini menggunakan purposive sampling, yaitu pengambilan sampel dengan kriteria tertentu. Beberapa kriteria sampel yang akan digunakan yaitu (1) Perusahaan jasa sektor konstruksi yang obligasinya beredar di Bursa Efek Indonesia, (2) Perusahaan jasa sektor konstruksi yang obligasinya tidak diperingkati oleh PT Pemeringkat Efek Indonesia (3) Perusahaan jasa sektor konstruksi yang obligasinya tidak diperingkati oleh PT Pemeringkat Efek Indonesia selama tahun 2013-2017. Berikut daftar sampel perusahaan:

Tabel 1. Daftar Sampel Perusahaan

\begin{tabular}{cl} 
No & Nama Emiten \\
\hline 1 & Adhi Karya (Persero), Tbk. \\
\hline 2 & Pembangunan Perumahan (Persero), Tbk. \\
\hline 3 & Waskita Karya (Persero), Tbk. \\
\hline 4 & Wijaya Karya (Persero), Tbk. \\
\hline 5 & Hutama Karya (Persero). \\
\hline 6 & Jasa Marga (Persero), Tbk. \\
\hline
\end{tabular}

Sumber : Diolah oleh peneliti, 2019

Data yang dibutuhkan dalam penelitain ini adalah data sekunder melalui teknik dokumentasi dan studi pustaka. yaitu data perusahaan yang mengeluarkan obligasi dan data peringkat obligasi perusahaan yang menerbitkan obligasi melalui website web.idx.id dan www.pefindo.com data tersebut berupa data annual report dan peringkat obligasi. Studi pustaka dilakukan dengan cara mempelajari berbagai literatur yang berhubungan dengan masalah yang diteliti untuk memperoleh landasan teori yang digunakan dalam penelitian ini. Sumber yang digunakan berasal dari buku, jurnal, dan artikel ilmiah.

Teknik pengolah data dengan analisis multivariate dengan menggunakan Regresi Logistik Ordinal (Ordinal Logistic Regression) karena variabel dependen yang digunakan berbentuk kategorial dan memiliki urutan. Tahapan dalam penelitian ini sebagai berikut, yaitu (1) Statistik deskriptif, digunakan untuk memberikan deskripsi suatu data yang dilihat dari rata-rata, standar deviasi dan nilai maksimum-minimum. (2) Model Fitting Information, untuk menilai overall fit model terhadap data dengan munggunakan fungsi Likelihood. (3) Goodness of Fit, untuk menguji kesesuaian antara model dengan data sehingga model dikatakan fit. (4) Pseudo R-Square, untuk melihat variabilitas variabel dependen yang dapat dijelaskan oleh variabel independent. (5) Uji Paralel Line, menguji apakah asumsi semua kategori memiliki parameter yang sama atau tidak. 


\section{ANALIS DAN HASIL}

Dalam penelitian ini, data diolah menggunakan Analisis Regresi Logistik Ordinal dengan menggunakan program SPSS untuk mengetahui hasil dari keempat variabel independen terhadap variabel dependennya. Model penelitian yang digunakan dalam penelitian ini adalah sebagai berikut:

$$
\text { Bond Rating }=\alpha+\mathrm{b}_{1} \mathrm{CR}+\mathrm{b}_{2} \mathrm{DER}+\mathrm{b}_{3} \mathrm{TAT}+\mathrm{b}_{4} \mathrm{NPM}+\mathrm{e}
$$

Keterangan adalah sebagai berikut:

Bond Rating $=$ Peringkat obligasi

$\alpha=$ Konstanta

$\mathrm{CR}=$ Current Ratio

DER = Debt to Equity Ratio

TAT $=$ Total Assets Turnover

NPM = Net Profit Margin

$\mathrm{b}_{1-4}=$ Koefisien Regresi

$\mathrm{e}=$ Error Term

Anilisis pertama yang digunakan untuk mengetahui pengaruh Current Ratio, Debt to Equity Ratio, Total Assets Turnover, dan Net Profit Margin terhadap peringkat obligasi dengan menggunakan analisis Model Fitting Information. Pengujian ini dilakukan untuk mengetahui ketepatan model terhadap data. Uji ketepatan model yang digunakan dalam penelitian ini adalah -2LogLikelihood, yaitu dengan membandingkan nilai -2LogLikelihood awal (intercept only) dengan model final. Adanya penurunan nilai -2LogLikelihood awal dengan -2LogLikelihood model final menunjukkan bahwa model regresi yang semakin baik. Hasil uji Model Fitting Information adalah sebagai berikut:

Tabel 2. Model Fitting Information

\begin{tabular}{lrrrrr}
\hline Model & \multicolumn{2}{l}{-2 Log Likelihood } & Chi-Square & df & Sig. \\
\hline Intercept Only & 81,635 & & & & \\
\hline Final & 51,319 & 30,315 & 4 &, 000 \\
\hline
\end{tabular}

Sumber : Output SPSS 21

Berdasarkan data diatas, menunjukkan perbandingan antara model dengan Intercept Only menghasilkan nilai -2LogLikelihood sebesar 81,635. Sedangkan jika variabel independen X1 sampai dengan X4 dimasukan kedalam model, maka akan menurunkan nilai -2LogLikelihood menjadi 51,319. Penurunan ini signifikan pada 0,000. Hal ini menunjukkan bahwa model dengan penambahan variabel independen lebih baik dibandingkan hanya dengan Intercept Only. Jadi, dapat disimpulkan bahwa model fit dengan data.

Pengujian kedua adalah Goodness of Fit Test, pengujian ini dilakukan untuk mengetahui kesesuaian model antara hipotesa nol sebagai data hasil prediksi model dengan data empiris. Hasil pengujian Goodness of Fit Test adalah sebagai berikut:

Tabel 3. Goodness-of-Fit

\begin{tabular}{lrrrr}
\hline & Chi-Square & df & \multicolumn{2}{c}{ Sig. } \\
\hline Pearson & 114,021 & 83 &, 014 \\
\hline Deviance & 51,319 & 83 &, 998
\end{tabular}

Sumber : Output SPSS 21 
Berdasarkan tabel diatas, Goodness of Fit Test tidak begitu relevan karena banyak cell yang memiliki frekuensi nol, oleh karena itu dapat diabaikan.

Pengujian ketiga adalah pengujian Pseudo R-Square, pengujian ini digunakan untuk mengetahui besarnya variabilitas variabel dependen yang dapat dijelaskan oleh variabel independen. Hasil pengujian Pseudo R-Square adalah sebagai berikut:

Tabel 4. Pseudo R-Square

\begin{tabular}{|lr|}
\hline Cox and Snell &, 636 \\
Nagelkerke &, 681 \\
McFadden &, 371 \\
\hline
\end{tabular}

Sumber : Output SPSS 21

Pada regresi logistik ordinal, untuk mengestimasikan nilai $\mathrm{R}^{2}$ menggunakan nilai McFadden. Berdasarkan tabel diatas, nilai pada tabel Pseudo R-Square McFadden sebesar 37,1\%. Nilai ini menjelaskan bahwa variasi peringkat obligasi yang dapat dijelaskan oleh variasi variabel independen X1 sampai dengan X4 sebesar 37,1\%. Sisanya 62,9\% dijelaskan oleh variabelvariabel lain di luar model penelitian.

Pengujian keempat adalah Test of Parallel Lines, pegujian ini digunakan untuk menguji apakah asumsi semua kategori memiliki parameter yang sama atau tidak. Parallel Lines terpenuhi apabila nilai yang diperoleh adalah tidak signifikan atau di atas $0,05(\rho>\alpha 0,05)$. Hasil pengujian Parallel Lines adalah sebagai berikut:

Tabel 5. Test of Parallel Lines

\begin{tabular}{lrrrl}
\hline Model & \multicolumn{1}{c}{ Log Likelihood } & Chi-Square & df & Sig. \\
\hline Null Hypothesis & 51,319 & & & \\
\hline General & $47,384 \mathrm{~b}$ & $3,936 \mathrm{c}$ & 8 &, 863 \\
\hline
\end{tabular}

Sumber : Output SPSS 21

Berdasarkan tabel diatas, hasil uji Parallel Lines menunjukkan nilai $\rho(0,863)>\alpha(0,05)$ yang dapat diartikan model yang dihasilkan memiliki parameter yang sama atau hubungan antara variabel independen dengan logit adalah sama untuk semua persamaan logit sehingga pemilihan link function telah sesuai.

Pengujaian terakhir adalah pengujian hipotesis, persamaan model Regresi Logistik Ordinal digunakan untuk mengetahui pengaruh variabel independen terhadap variabel bebas secara parsial. Hasil analisis regresi logistik ordinal dapat dilihat pada tabel berikut:

Tabel 6. Parameter Estimates

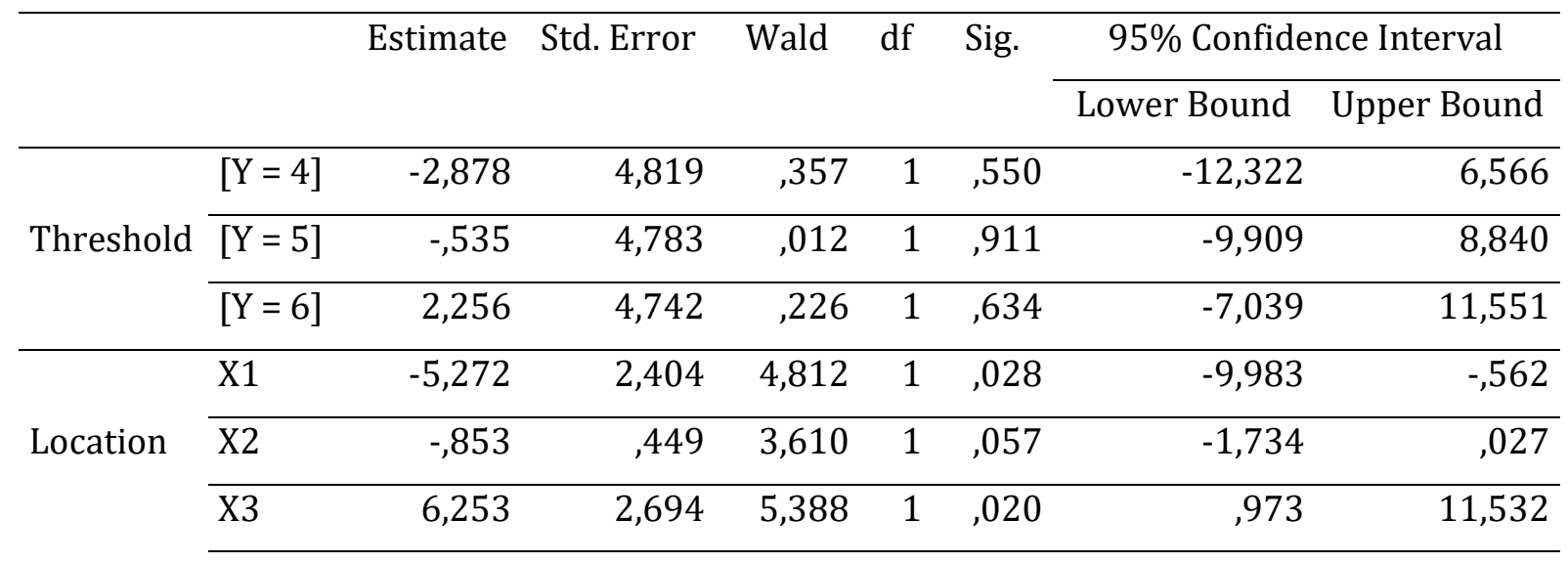




\begin{tabular}{llllllll}
\hline $\mathrm{X} 4$ & 63,332 & 28,331 & 4,997 & 1 &, 025 & 7,804 & 118,861
\end{tabular}

Sumber : Output SPSS 21

Jika nilai sig. $<0,05$ maka dapat dikatakan bahwa variabel independen berpengaruh terhadap variabel dependen, dan didapatkan persamaan yang terbentuk sebagai berikut :

$$
\text { Bond Rating }=\alpha-5,272 \mathrm{X}_{1}-0,853 \mathrm{X}_{2}+6,253 \mathrm{X}_{3}+63,332 \mathrm{X}_{4}+\mathrm{e}
$$

\section{Pengaruh Current Ratio terhadap Peringkat Obligasi}

Hipostesis satu menyebutkan bahwa hasil Analisis Regresi Logistik ordinal menghasilkan koefisien regresi variabel rasio likuiditas yang diproksikan dengan Current Ratio adalah sebesar 5,272 dengan nilai signifikansi $(0,028)<\alpha(0,05)$, yang berarti bahwa Current Ratio secara parsial berpengaruh negatif dan signifikan terhadap peringkat obligasi. Setiap kenaikan 1unit Current Ratio akan menurunkan odd ratio peringkat obligasi sebesar exp $(-5,272)$ dengan asumsi variabel lainnya ceteris paribus.

Hal ini tidak sesuai dengan teori yang ada, yang menyatakan bahwa rasio likuiditas secara spesifik mencerminkan ketersedian dana yang dimiliki perusahaan guna memenuhi semua hutang yang akan jatuh tempo (Syafrida Hani, 2015: 121). Dari keseluruhan sampel yang diteliti dapat dilihat bahwa data likuiditas yang dimiliki oleh perusahaan dengan nilai likuiditas maksimum, memiliki peringkat obligasi terendah. Namun sebaliknya, perusahaan dengan nilai likuiditas minimum, memiliki peringkat obligasi tertinggi. Current Ratio yang terlalu tinggi dianggap tidak baik karena mengindikasikan adanya pengelolaan aset yang tidak efektif seperti penimbunan kas, banyaknya piutang yang tidak tertagih, tidak efisiennya pemanfaatan pembiayaan dari pemasok dan rendahnya pinjaman jangka pendek. Dengan demikian, dapat disimpulkan bahwa $\mathrm{H}_{1}$ diterima, Current Ratio berpengaruh terhadap peringkat obligasi. Perusahaan dengan nilai Current Ratio yang tinggi, cenderung menghasilkan peringkat obligasi yang rendah.

Hasil penelitian ini sesuai dengan penelitian sebelumnya yang dilakukan oleh Fitria, Mareka dan Paulus (2016) dan Anita Febriani (2017) yang menyatakan bahwa Current Ratio berpengaruh negatif dan signifikan terhadap peringkat obligasi. Penelitian ini berbeda dengan penelitian Dian Wahyu Kurniawan (2016) dan Akbar Sunanto (2015) yang menyatakan bahwa Current Ratio tidak berpengaruh terhadap peringkat obligasi, serta penelitian Rizka Dewi Oktaviyani (2013) yang menyatakan bahwa Current Ratio berpengaruh positif dan signifikan terhadap peringkat obligasi.

\section{Pengaruh Debt to Equity Ratio terhadap Peringkat Obligasi}

Hipostesis kedua menyebutkan bahwa hasil analisis Regresi Logistik Ordinal menghasilkan koefisien regresi variabel rasio solvabilitas yang diproksikan dengan Debt Equity Ratio adalah sebesar $-0,853$ dengan nilai signifikansi $(0,057)>\alpha(0,05)$, yang berarti bahwa Debt Equity Ratio secara parsial tidak berpengaruh signifikan terhadap peringkat obligasi.

Hal ini tidak sesuai dengan teori yang ada, yang menyatakan bahwa rasio solvabilitas adalah rasio yang menunjukkan bagaimana perusahaan mampu untuk mengelola hutangnya dalam rangka memperoleh keuntungan dan juga mampu untuk melunasi kembali hutangnya (Irham Fahmi, 2014: 59). Dari keseluruhan sampel yang diteliti dapat dilihat bahwa, data solvabilitas yang dimiliki oleh perusahaan dengan nilai solvabilitas maksimum maupun minimum, memiliki peringkat obligasi yang sama. Nilai rata-rata Debt to Equity Ratio dalam penelitian menunjukkan nilai yang tinggi, yaitu sebesar 3,054. Rasio yang tinggi mengindikasikan bahwa perusahaan lebih banyak menggunakan pendanaan yang bersumber dari pihak eksternal, yaitu berupa utang. Debt to Equity Ratio tidak selalu menjelaskan kinerja emiten yang buruk ataupun fundamental 
keuangan yang lemah. Keidealan Debt to Equity Ratio tidak bisa diterapkan disemua sektor, karena tergantung kepada kemapanan bisnisnya. Dengan demikian, dapat disimpulkan bahwa $\mathrm{H}_{2}$ ditolak, Debt to Equity Ratio tidak memberikan pengaruh terhadap peringkat obligasi perusahaan.

Hasil penelitian ini sesuai dengan penelitian sebelumnya yang dilakukan oleh Dian Wahyu Kurniawan (2016) dan Amerilia Safitri (2014) yang menyatakan bahwa Debt to Equity Ratio tidak berpengaruh signifikan terhadap peringkat obligasi. Penelitian ini berbeda dengan penelitian Rachmat Dwi Winardi (2013) dan Nur Latiffah Rukmana (2016) yang menyatakan bahwa Debt Equity Ratio berpengaruh negatif dan signifikan terhadap peringkat obligasi.

\section{Pengaruh Total Assets Turnover terhadap Peringkat Obligasi}

Hipostesis ketiga menyebutkan bahwa hasil Analisis Regresi Logistik Ordinal menghasilkan koefisien regresi variabel rasio aktivitas yang diproksikan dengan Total Assets Turnover adalah sebesar 6,253 dengan nilai signifikansi $(0,020)<\alpha(0,05)$, yang berarti bahwa Total Assets Turnover secara parsial berpengaruh positif dan signifikan terhadap peringkat obligasi. Setiap kenaikan 1unit Total Assets Turnover akan menurunkan odd ratio peringkat obligasi sebesar exp $(6,253)$ dengan asumsi variabel lainnya ceteris paribus. Dengan demikian, dapat disimpulkan bahwa perusahaan dengan nilai Total Assets Turnover yang tinggi, cenderung menghasilkan peringkat obligasi yang tinggi.

Hasil ini telah sesuai dengan teori yang ada, yang menyatakan bahwa rasio aktivitas menggambarkan sejauh mana perusahaan mempergunakan sumber daya yang dimilikinya guna menunjang aktivitas perusahaan, dimana penggunaan aktivitas ini dilakukan secara sangat maksimal dengan maksud memperoleh hasil yang maksimal (Irham Fahmi, 2014: 132). Total Assets Turnover memberikan indikasi kemampuan perusahaan untuk going concern. Semakin tinggi Total Assets Turnover perusahaan, menandakan semakin baik pula kemampuan perusahaan dalam menjalankan aktivitas perusahaan guna medapatkan hasil yang maksimal untuk melunasi kewajibannya. Kemampuan perusahaan tersebut dapat dijadikan sebagai sinyal positif yang akan menarik investor. Sehingga, semakin tinggi Total Assets Turnover akan menaikkan peringkat obligasi. Sehingga dapat disimpulkan, $\mathrm{H}_{3}$ diterima, Total Assets Turnover berpengaruh terhadap peringkat obligasi.

Hasil penelitian ini sesuai dengan penelitian sebelumnya yang dilakukan oleh Dian Wahyu Kurniawan (2016) menyatakan bahwa Total Assets Turnover berpengaruh positif dan signifikan terhadap peringkat obligasi. Penelitian ini berbeda dengan penelitian Akbar Sunanto (2015) dan Amerilia Safitri (2014) yang menyatakan bahwa Total Assets Turnover tidak berpengaruh signifikan terhadap peringkat obligasi.

\section{Pengaruh Net Profit Margin terhadap Peringkat Obligasi}

Hipostesis keempat menyebutkan bahwa hasil Analisis Regresi Logistik Ordinal menghasilkan koefisien regresi variabel rasio profitabilitas yang diproksikan dengan Net Profit Margin adalah sebesar 62,332 dengan nilai signifikansi $(0,025)<\alpha(0,05)$, yang berarti bahwa Net Profit Margin secara parsial berpengaruh positif dan signifikan terhadap peringkat obligasi. Setiap kenaikan 1unit Net Profit Margin akan menurunkan odd ratio peringkat obligasi sebesar exp $(63,332)$ dengan asumsi variabel lainnya ceteris paribus. Dengan demikian, dapat disimpulkan bahwa H4 diterima, Net Profit Margin berpengaruh terhadap peringkat obligasi. Perusahaan dengan nilai Net Profit Margin yang tinggi, cenderung menghasilkan peringkat obligasi yang tinggi. 
Hasil ini telah sesuai dengan teori yang ada, yang menyatakan bahwa rasio profitabilitas merupakan ukuran untuk menilai kemampuan perusahaan dalam mencari keuntungan. Rasio ini juga memberikan ukuran tingkat efektivitas manajemen suatu perusahaan (Kasmir, 2013: 196). Net Profit Margin memberikan indikasi kemampuan perusahaan untuk going concern. Semakin tinggi Net Profit Margin perusahaan, semakin baik pula kemampuan perusahaan dalam membayar bunga periodik dan melunasi pinjaman pokok obligasi. Kemampuan perusahaan tersebut dapat dijadikan sebagai sinyal positif yang akan menarik investor. Sehingga, semakin tinggi Net Profit Margin akan menaikkan peringkat obligasi.

Hasil penelitian ini sesuai dengan penelitian sebelumnya yang dilakukan oleh Nur Latiffah Rukmana (2016) yang menyatakan bahwa Net Profit Margin berpengaruh positif dan signifikan terhadap peringkat obligasi. Penelitian ini berbeda dengan penelitian Rachmat Dwi Winardi (2013) yang menyatakan bahwa Net Profit Margin tidak berpengaruh signifikan terhadap peringkat obligasi.

\section{KESIMPULAN}

Variable rasio aktivitas dan profitabilitas berpengaruh secara positif terhadap peringkat obligasi. Rasio likuiditas berpengaruh negatif terhadap peringkat obligasi, sedangkan rasio solvabilitas tidak berpengaruh terhadap peringkat obligasi. Keterbatasan dalam penelitian ini adalah hanya menguji pengaruh rasio likuiditas, solvabilitas, aktivitas, dan profitabilitas yang diproksikan oleh satu jenis rasio. Subjek penelitian terbatas hanya perusahaan jasa kontruksi yang terdaftar di BEI dan obligasinya diperingkati oleh PT PEFINDO. Jumlah sampel dalam penelitian ini masih sangat terbatas.

Saran kepada investor sebaiknya lebih selektif dalam berinvestasi obligasi dengan memperhatikan laporan keuangan agar terhindar dari kerugian dalam berinvestasi. Untuk peneliti selanjutnya dianjurkan untuk menambahan jumlah sampel perusahaan dan variabel lainnya selain faktor keuangan, sehingga hasil yang diperoleh lebih baik dan memperkuat hasil penelitian.

\section{DAFTAR PUSTAKA}

Brigham, Eugene F dan Houston, Joel F. (2014). Dasar-Dasar Manajemen Keuangan. Edisi 11 Buku 1. Terjemahan oleh Ali Akbar Yulianto dari Fundamentals of Financial Management. Jakarta: Salemba Empat.

Caesario, E. B. (2018, Februari 12). SURAT UTANG KORPORASI: Waspadai Obligasi Sektor Konstruksi. Retrieved Oktober 08, 2018, from Market Bisnis: http://market.bisnis.com

Dwi Winardi, R. (2013). Faktor Akuntansi dan Non Akuntansi yang Mempengaruhi Prediksi Peringkat Obligasi.

Fahmi, Irham. (2014). Analisis Laporan Keuangan. Bandung: Alfabeta.

Febriani, A. Pengaruh Likuiditas, Profitabilitas, Leverage, Dan Audit Tenure Terhadap Peringkat Obligasi.

Fitria, M.R. \& Paulus, S. K. Pengaruh Current Ratio, Debt to Equity Ratio dan Return on Asset Terhadap Peringkat Obligasi Pada Perusahaan LQ 45 Yang Terdaftar di Bursa Efek Indonesia Periode 2011-2015 
Hani, Syafrida. (2015). Teknik Analisa Laporan Keuangan. Medan: UMSU Press.

Harahap, S. S. (2011). Analisis Kritis atas Laporan Keuangan. Jakarta: PT. Raja Gafindo Persada Pers.

Kasmir. (2013), Analisis Laporan Keuangan. Jakarta: PT. Raja Grafindo Persada.

Kustiyaningrum, D., Nuraina, E., \& Wijaya, A. L. (2016). Pengaruh Leverage, Likuiditas, Profitabilitas, dan Umur Obligasi terhadap Peringkat Obligasi (Studi pada Perusahaan Terbuka yang Terdaftar di Bursa Efek Indonesia). Assets: Jurnal Akuntansi dan Pendidikan, $5(1), 25-40$.

Kurniawan, Dian Wahyu. (2016). Kemampuan Rasio Keuangan Untuk Memprediksi Peringkat Obligasi Perusahaan Non Jasa Keuangan Yang Terdaftar Di Bursa Efek Indonesia.

Latiffah Rukmana, R. (2016). Pengaruh Rasio Keuangan Dan Ukuran Perusahaan (Size) Terhadap Peringkat Obligasi Perusahaan Perbankan Yang Terdaftar Di Bursa Efek Indonesia Tahun 2011-2015.

Mahfudhoh, R. U. (2014). Analisis Faktor-Faktor Yang Mempengaruhi Peringkat Obligasi

Munawir, S. (2015). Analisis Laporan Keuangan. Jakarta: Salemba Empat

Oktaviyani, R. D. (2013). Pengaruh Manajemen Laba, Rasio Keuangan dan Mekanisme Corporate Governance Terhadap Peringkat Obligasi

Partha, M. B., \& Yasa, G. W. (2016). Kemampuan Rasio Keuangan Dalam Memprediksi Peringkat Obligasi Pada Perusahaan Sektor Non Keuangan. E-Jurnal Akuntansi, 1913-1941.

Safitri, A. (2014). Analisis Faktor-Faktor Yang Mempengaruhi Peringkat Obligasi Perusahaan Manufaktur Yang Terdaftar Di Bursa Efek Indonesia

Susanto, A. (2015). Faktor-Faktor Yang Mempengaruhi Peringkat Obligasi Pada Perusahaan Non Keuangan Tahun 2011-2013 